\section{JURNAL ABDIMAS

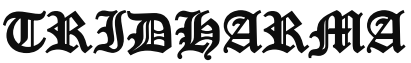

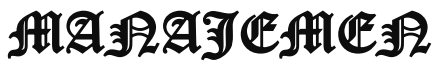

P-ISSN 2615-6849, E-ISSN 2716-070X

Jurnal ABDIMAS Vol. 1,No.2, Mei 2020,Hal(56-66)

@ Prodi Manajemen Fakultas Ekonomi Universitas Pamulang

Email: abdimasjurnal.unpam@gmail.com Telp: (021) 741-2566

\title{
MOTIVASI UNTUK MENINGKATKAN KINERJA SUMBER DAYA MANUSIA PADA KELURAHAN PISANGAN
}

\author{
Derita Qurbani, Styo Budi Utomo, Hira Maulida, Supardi, Bulan Oktrima \\ Dosen Ekonomi Fakultas Ekonomi Universitas Pamulang \\ Emaildosen01582@unpam.ac.id, dosen01759@unpam.ac.id, \\ dosen02450@unpam.ac.id, dosen00790@unpam.ac.id
}

\begin{abstract}
ABSTRAK
Pengabdian ini berjudul Motivasi Untuk Meningkatkan Kinerja Sumber Daya Manusia Pada Kelurahan Pisangan. Tujuan pengabdian ini adalah untuk meningkatkan motivasi karyawan kelurahan pisangan. Membentuk sumber daya manusia yang memiliki motivasi tinggi. Mewujudkan sumber daya manusia yang memiliki kinerja yang baik.

Metode pelaksanaan pengabdian ini dilakukan dalam beberapa kegiatan yaitu tahap survei yaitu sosialisasi dilakukan dengan menyusun berbagai hal yang akan disampaikan pada saat kegiatan pengabdian yang akan dilakukan yang meliputi: penyusunan materi yang akan diberikan, penyusunan jadwal pemberian materi, pembagian tugas tim pengabdian dan survei ke lokasi pengabdian di kelurahan Pisangan, Ciputat Timur. Tahap sosialisasi yaitu sebelum kegiatan pengabdian dilaksanakan terlebih dahulu dilakukan tahap sosialisasi yaitu melakukan silaturahmi, menyampaikan maksud dan tujuan pengabdian ini. Pada tahap ini juga dilakukan jalinan kerjasama dan menentukan jadwal kegiatan pengabdian. Tim pelaksana kegiatan pengabdian pada masyarakat adalah dosen Fakultas Ekonomi jurusan manajemen sebanyak 5 orang. Tim pengabdian memberikan materi tentang pentingnya ilmu manajemen, dengan menitikberatkan pada penjelasan mengenai bagaimana menjadi sumber daya manusia yang berkualitas dan inovatif, serta pengembangan motivasi kerja karyawan. Selanjutnya dilakukan tahap sharing pengalaman atau pun diskusi tanyajawab.

Kesimpulan dari pengabdian ini adalah karyawan membutuhkan motivasi untuk meningkatkan kinerja sehingga diharapkan pihak Kelurahan memperhatikan lagi bentuk motivasi kerja pegawai seperti prestasi, karena apabila pegawai merasa termotivasi dalam bekerjanya maka kinerja juga akan lebih baik lagi, dengan cara pimpinan memberikan penghargaan kepada pegawai yang memiliki kemampuan dan memiliki prestasi. Tingginya motivasi kerja yang membuat pegawai nyaman dan sigap dalam mengerjakan tugasnya Pimpinan harus mengadakan pelatihan/sosialisasi tentang tugas dan fungsi sebagai karyawan atau pegawai dalam menunjang pelaksanaan tugas dan fungsi kerjanya. Sebagai bahan masukan untuk sejauh mana mengevaluasi pegawai tentang motivasi kerja serta memperhatikan unsur-unsur apa yang membuat pegawai termotivasi dalam meningkatkan kinerja, sehingga nantinya tidak merugikan Aparatur.
\end{abstract}

\section{Kata Kunci: Motivasi, Kinerja Sumber Daya Manusia}

\section{MOTIVATION TO IMPROVE PERFORMANCE OF HUMAN RESOURCES IN KELURAHAN PISANGAN}

\section{ABSTRACT}

This service is titled Motivation to Improve the Performance of Human Resources in Pisangan Kelurahan. The purpose of this service is to increase the 


\section{JURNAL ABDIMAS

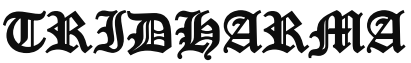

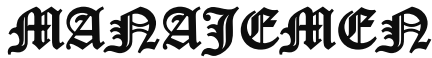

P-ISSN 2615-6849, E-ISSN 2716-070X

Jurnal ABDIMAS Vol. 1,No.2, Mei 2020,Hal(56-66)

@ Prodi Manajemen Fakultas Ekonomi Universitas Pamulang

Email: abdimasjurnal.unpam@gmail.com Telp: (021) 741-2566

motivation of Kelurahan Pisangan employees. Forming highly motivated human resources. Realizing human resources that have good performance.

The method of implementing this service is carried out in a number of activities, namely the survey stage, namely the socialization carried out by compiling various things that will be delivered at the time of service activities that will be carried out which include: preparation of material to be given, preparation of material delivery schedule, division of tasks of the service team and survey to the location community service in Kelurahan Pisangan, East Ciputat. The socialization phase is before the community service activity is carried out first, the socialization phase is to do a gathering, conveying the aims and objectives of this service. At this stage also carried out the fabric of cooperation and determine the schedule of service activities. The implementing team of community service activities are 5 lecturers from the Faculty of Economics majoring in management. The dedication team provides material on the importance of management science, with an emphasis on explaining how to become quality and innovative human resources, as well as developing employee work motivation. The next step is sharing experience or question and answer discussion.

The conclusion of this dedication is that employees need motivation to improve performance so that it is hoped that Kelurahan Pisangan will pay more attention to employee work motivation forms such as achievement, because if employees feel motivated in their work then performance will also be better, by the way the leader gives rewards to employees who have the ability and have achievements. High work motivation that makes employees comfortable and alert in carrying out their duties. Leaders must conduct training / outreach on tasks and functions as employees or employees in supporting the implementation of their work duties and functions. As input for the extent to which evaluates employees about work motivation and pay attention to what elements make employees motivated in improving performance, so that later it does not harm the Apparatus.

\section{Keywords: Motivation, Performance of Human Resources}

\section{PENDAHULUAN}

\section{Analisis Situasi Permasalahan}

Kelurahan Pisangan adalah Keadaan

Geografis dan Demografi Kelurahan atau desa adalah pembagian wilayah administratif di Indonesia, dibawah Kecamatan. Dalam konteks otonomi daerah di Indonesia, kelurahan merupakan wilayah kerja lurah sebagai perangkat Daerah Kabupaten atau kota. Kelurahan dipimpin oleh seorang lurah. Kelurahan merupakan unit pemerintahan terkecil setingkat dengan desa. Berbeda dengan desa, kelurahan memiliki hak mengatur wilayahnya lebih terbatas. Dalam perkembangannya, sebuah desa dapat ditingkatkan statusnya menjadi kelurahan. Kelurahan Pisangan yang terletak pada bagian utara berbatasan dengan kelurahan Cirendeu atau Karang Tengah-Jakarta Selatan. Untuk selatan berbatasan dengan kelurahan Cipayung atau Pondok Cabe Udik, sebelah timur berbatasan dengan kelurahan Pondok Cabe Udik atau Cinere Sawangan Depok dan pada sebelah barat yang berbatasan dengan kelurahan Cipayung atau Cempaka Putih.

Kelurahan pisangan yang memiliki lokasi strategis pastinya akan mampu lebih maju dan berkembang. karena dilihat dari letak geografisnya berbatasan langsung dengan wilayah administratif Jakarta Selatan Propinsi DKI Jakarta baik secara ekonomi maupun secara sosial. suesuai uraian diatas terkait dengan sumber daya manusia, maka sumber daya manusia merupakan aset utama dalam sebuah 


\section{JURNAL ABDIMAS

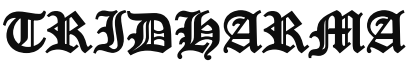

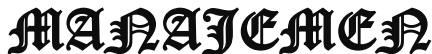

P-ISSN 2615-6849, E-ISSN 2716-070X

Jurnal ABDIMAS Vol. 1,No.2, Mei 2020,Hal(56-66)

@Prodi Manajemen Fakultas Ekonomi Universitas Pamulang

Email: abdimasjurnal.unpam@ gmail.com Telp: (021) 741-2566 organisasi. Sumber daya mausia sering disebut dengan karyawan, staf, atau pegawai. Keberadaan sumber daya manusia didalam suatu perusahaan memegang peranan yang sangat penting. Tenaga kerja yang memiliki potensi besar untuk menjalankan aktifitas organisasi. Potensi setiap sumber daya mausia yang ada dalam organisasi harus dapat dimanfaatkan sebaik-baiknya. Sehingga mampu memberikan hasil yang maksimal.

Organisasi dan karyawan merupakan dua hal yang saling membutuhkan. Jika karyawan berhasi lmembawa kemajuan bagi organisasi, keuntungan yang diperoleh akan dipetik oleh kedua belah pihak. Bagi karyawan keberhasilan merupakan aktualisasi potensi diri sekaligus peluang untuk memenuhi kebutuhan hidupnya. Sedangkan bagi organisasi keberhasilan merupakan sarana menuju pertumbuhan dan perkembangan organisasi. Sumber daya manusia merupakan satu-satunya yang memiliki akal perasaan, keinginan, pengetahuan, dorongan, daya dan karya bagi seorang karyawan merupakan investasi utama dan harus diakui akan keberadaannya sebagai unci utama bahkan menjadi faktor penentu atas keberhasilan suatu organisasi dalam menjalankan visi, misi dan tujuan organisasi. Itulah sebabnya mengapa peran penting manusia sangat besar pengaruhnya sebagai motor penggerak dan agen perubahan.

Keberadaa semua oragnisasi mengharapkan semua sumber daya harus dapat bersinergi dan berjalan dengan seimbang.pengembangan sumber daya manusia yang adadalam lingkungan organisasi merupakan suatu proses peningkatan kualitas atau kemampuan manusia dalam rangka mencapai tujuan organisasi. Tujuan organisasi dapat diraih semaksimal mungkin apabila didukung dnegan kinerja yang baik dari para karyawan.untuk mendapatkan kinerja yang baik dari karyawan maka harus diupayakan pengarahan yang terstruktur dan efektif. Organisasi dalam upaya menggerakkan semua karyawan agar mau bekerja lebih produktif lagi sesuai dengan tujuan perusahaan yang telah ditetapkan. Sesuai dengan di lapangan masih ada karyawan yang masih kurang disiplin, jam kedatangan tidak tepat waktu dan masih kurang optimalmya kinerja pad Kel. Pisangan. Oleh karena itu kami mengadakan kegiatan Pengabdian Kepada Masyarakat (PKM) yang akan dilaksanakan pada di kelurahan Pisangan Kec. Ciputat Timur Kota Tangerang Selatan Propinsi Banten pada tanggal 25 28 Januari 2020.

Dalam kegiatan Pengabdian Kepada Masyarakat (PKM) yang akan dilakasakan pada di kelurahan PIsangan Kec. CIputat Timur Kota Tangerang Selatan Propinsi Banten berharap dapat memberikan solusi untuk karyawan dan staf kelurahan tersebut. adapun solusi yang akan dicapai dalam kegiatan ini minimal kinerja semua staf dan karyawan pada kelurahan tersebut sudah dapat membangkitkan kinerja. mengutip dari Rencana Strategis merupakan suatu proses yang berorientasi kepada hasil yang ingin dicapai selama kurun waktu satu sampai dengan lima tahun dengan memperhitungkan potensi, peluang, dan kendala yang ada atau yang mungkin timbul.

Rencana strategis mengandung visi, misi, tujuan, sasaran, serta cara pencapaian yang realistis untuk mengantisipasi perkembangan masa depan. Sebagaimana tertuang dalam Undang-undang Nomor 32 Tahun 2004 tentang Pemerintahan Daerah, pada Pasal 151 ayat (1), yang berbunyi :'Satuan Kerja Perangkat Daerah menyusun rencana strategis yang selanjutnya disebut Renstra SKPD memuat visi, misi, tujuan, strategi, kebijakan, program, dan kegiatan pembangunan sesuai dengan tugas dan fungsinya, berpedoman pada RPJMD daerah dan bersifat indikatif". Selanjutnya dipertegas lagi dalam Undang-undang Nomor 25 Tahun 2004 tentang Sistem Perencanaan Nasional dalam Pasal 1 ayat (7) yang menyatakan : "Renstra SKPD sebagai 


\section{JURNAL ABDIMAS

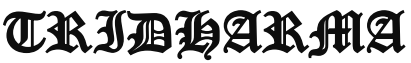

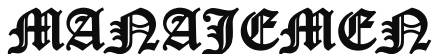

P-ISSN 2615-6849, E-ISSN 2716-070X

Jurnal ABDIMAS Vol. 1,No.2, Mei 2020,Hal(56-66)

@Prodi Manajemen Fakultas Ekonomi Universitas Pamulang

Email: abdimasjurnal.unpam@ gmail.com Telp: (021) 741-2566 dokumen perencanaan Satuan Kerja Perangkat Daerah untuk periode 5 (lima) tahun".

Berdasarkan pengertian tersebut di atas, dapatlah disimpulkan bahwa Renstra SKPD merupakan dokumen perencanaan SKPD untuk periode 5 (lima) tahun yang memuat visi, misi, strategi dan kebijakan, program dan indikasi kegiatan pembangunan yang disusun sesuai dengan tugas dan fungsinya untuk mencapai tujuan dan sasaran jangka menengah SKPD yang selaras dengan strategi dan kebijakan daerah sebagaimana tertuang dalam Rencana Pembangunan Jangka Menengah Daerah (RPJMD). Berdasarkan Undangundang Nomor 23 Tahun 2014 tentang Pemerintahan Daerah, Kecamatan merupakan satuan wilayah kerja atau pelayanan dan menjadi perangkat daerah kabupaten/kota yang setara dengan dinas dan lembaga teknis daerah sebagaimana dinyatakan dalam Pasal 209 Undangundang Nomor 23 Tahun 2014 yakni : "Perangkat daerah kabupaten/kota terdiri atas sekretariat daerah, sekretariat DPRD, dinas daerah, inspektorat, dinas, badan, dan kecamatan". Kecamatan sebagai satuan kerja perangkat daerah mempunyai peranan penting dalam pelaksanaan pelayanan terhadap masyarakat, dimana hal ini yang kemudian menjadikan Camat sebagai ujung tombak dalam pelaksanaan tugas-tugas umum pemerintahan serta sebagian urusan otonomi yang dilimpahkan oleh Bupati/ Walikota untuk dilaksanakan dalam wilayah kecamatan.

Selain melaksanakan tugas-tugas umum pemerintahan Camat juga melaksanakan kewenangan pemerintahan yang dilimpahkan oleh pemerintahan di atasnya untuk menangani sebagian urusan otonomi daerah, yang meliputi aspek perizinan, rekomendasi, koordinasi, pembinaan, pengawasan, fasilitasi, penetapan, penyelenggaraan, kewenangan lain yang dilimpahkan. Hal tersebut menjadikan Camat pada posisi strategis dalam penyelenggaraan pelayanan publik setelah kabupaten/kota, sekaligus menjalankan fungsi kontrol atas pelayanan publik yang dilaksanakan oleh pemerintah desa. Kecamatan sebagai salah satu perangkat daerah memiliki fungsi melayani kebutuhan masyarakat dengan permasalahan kompleks yang membutuhkan pelayanan prima dan aparatur pelayanan yang profesional.

Kompleksitas masalah yang dihadapi berkaitan erat dengan banyaknya jumlah penduduk yang dilayani, dan heterogenitas masyarakat pada berbagai hal di wilayah kecamatan, baik tingkat pendidikan, pekerjaan, kemampuan ekonomi, kesehatan, dan lain sebagainya. Sejalan dengan besarnya tuntutan masyarakat terhadap tata kelola pemerintahan yang baik, kebutuhan terhadap pelayanan publik yang berkualitas juga semakin besar diperlukan perencanaan pembangunan yang sistematis, terarah, menyeluruh dan responsif terhadap perkembangan kebutuhan masyarakat. Untuk merespon hal tersebut maka Kecamatan Ciputat Timur sebagai salah satu SKPD di lingkungan Pemerintah Kota Tangerang Selatan menyusun Rencana Strategis (Renstra) periode 2016-2021. sesuai isi rencana startegis kec. Citpuatat Timur antara lain berisi Membina penyelenggaraan pemerintahan desa dan/atau kelurahan, Melaksanakan pelayanan masyarakat yang menjadi ruang lingkup tugasnya dan/atau yang belum dapat dilaksanakan pemerintahan desa/ kelurahan dan Membina dan mengawasi penyelenggaraan kegiatan Kelurahan. Dalam kegiatan pengabdian kepada masyarakat ini sangat membatu dalam pelaksanaan dan pencapaian tujuan dari rencana strategis kec. Ciputat Timur.

\section{Rumusan Masalah}

Adapun perumusan masalah adalah :

1. Bagaimana implementasi ilmu manajemen dalam meningkatkan motivasi karyawan kelurahan pisangan? 


\section{JURNAL ABDIMAS

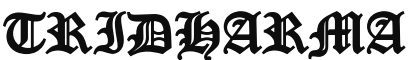

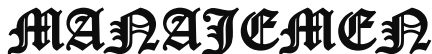

P-ISSN 2615-6849, E-ISSN 2716-070X

Jurnal ABDIMAS Vol. 1,No.2, Mei 2020,Hal(56-66)

@Prodi Manajemen Fakultas Ekonomi Universitas Pamulang

Email: abdimasjurnal.unpam@gmail.com Telp: (021) 741-2566
2. Bagaimana membentuk sumber daya manusia yang memiliki motivasi tinggi dalam bekerja?

3. Bagaimana mewujudkan sumber daya manusia yang memiliki kinerja yang efektif dan efisien?

\section{Tujuan Pengabdian kepada Masyarakat}

1. Meningkatkan motivasi karwayan kelurahan pisangan.

2. Membentuk sumber daya manusia yang memiliki motivasi tinggi.

3. Mewujudkan sumber daya manusia yang memiliki kinerja yang baik.

\section{Manfaat Pengabdian kepada}

\section{Masyarakat}

1. Sebagai bentuk pengabdian dosen untuk masyarakat.

2. Sebagai tugas tridharma perguruan tinggi.

3. Memberikan manfaat bagi karyawan agar meng-upgrade motivasinya dalam bekerja.

\section{TINJAUAN PUSTAKA}

\section{Pengertian Motivasi}

Motivasi merupakan suatu proses dimana kebutuhan-kebutuhan mendorong seseorang untuk melakukan serangkaian kegiatan yang mengarah ketercapainya tujuan tertentu, jika brrhasil dicapai, akan memuaskan atau memenuhi kebutuhankebutuhan tersebut (Munandar, 2010). Motivasi merupakan pemberian atau penimbulan motif, dan hal atau keadaan yang menimbulkan motif, jadi motivasi kerja merupakan sesuatu yang menimbulkan semangat atau dorongan kerja, dimana kuat atau lemahnya motivasi kerja seorang tenaga kerja ikut menentukan besar kecil prestasi (Wexley dan Yukl dalam As'ad, 2002).

Motivasi adalah karakteristik psikologis pada aktifitas manusia untuk memberi kontribusi berupa tingkat komitmen seseorang termasuk faktorfaktor yang menyebabkan, menyalurkan dan mempertahankan tingkah laku manusia dalam arah tekad tertentu untuk mencapai keinginan. Aktifitas yang dilakukan adalah aktifitas yang bertujuan agar terpenuhi keinginan individu. Menurut Siagian (2011), mendefinisikan motivasi kerja sebagai daya dorong bagi seseorang untuk memberikan kontribusi yang sebesarbesarnya demi keberhasilan organisasi mencapai tujuannya, dengan pengertian bahwa tercapainya tujuan organisasi berarti tercapai pula tujuan pribadi para anggota organisasi yang bersangkutan. Sementara Robbins (2008) mengatakan motivasi kerja sebagai kesediaan untuk mengeluarkan tingkat upaya yang tinggi kearah tujuantujuan organisasi, yang dikondisikan oleh kemampuan upaya tersebut untuk memenuhi suatu kebutuhan individu.

Motivasi kerja merupakan suatu modal dalam menggerakkan dan mengarahkan para karyawan atau pekerja agar dapat melaksanakan tugasnya masing-masing dalam mencapai sasaran dengan penuh kesadaran, kegairahan dan bertanggung jawab (Hasibuan, 2008). Berdasarkan uraian di atas, dapat disimpulkan bahwa motivasi kerja adalah suatu daya penggerak yang mampu menciptakan kegairahan kerja dengan membangkitkan, mengarahkan, dan berperilaku kerja serta mengeluarkan tingkat upaya untuk memberikan kontribusi yang sebesar besarnya demi keberhasilan organisasi dalam mencapai tujuannya.

\section{Faktor-faktor Yang Mempengaruhi Motivasi Kerja}

Menurut Siagian faktor yang mempengaruhi motivasi kerja seseorang dapat diketahui berdasarkan karakteristik dari individu yang bersifat khas yang terdiri dari delapan faktor yaitu:

a. Karakteristik biografi yang meliputi:

1) Usia, hal ini penting karena usia mempunyai kaitan yang erat dengan berbagai segi kehidupan organisasional. Misalnya kaitan usia dengan tingkat kedewasaan teknis yaitu ketrampilan tugas. 


\section{JURNAL ABDIMAS

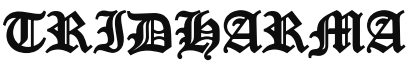

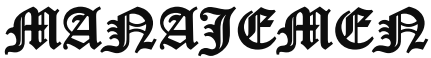

P-ISSN 2615-6849, E-ISSN 2716-070X

Jurnal ABDIMAS Vol. 1,No.2, Mei 2020,Hal(56-66)

@Prodi Manajemen Fakultas Ekonomi Universitas Pamulang

Email: abdimasjurnal.unpam@gmail.com Telp: (021) 741-2566
2) Jenis kelamin, karena jelas bahwa implikasi jenis kelamin para pekerja merupakan hal yang perlu mendapat perhatian secara wajar dengan demikian perlakuan terhadap merekapun dapat disesuaikan sedemikian rupa sehingga mereka menjadi anggota organisasi yang bertanggung jawab terhadap pekerjaannya.

3) Status perkawinan, dengan status ini secara tidak langsung dapat memberikan petunjuk cara, dan teknik motivasi yang cocok digunakan bagi para pegawai yang telah menikah dibandingkan dengan pegawai yang belum menikah.

4) Jumlah tanggungan, dalam hal ini jumlah tanggungan seorang seorang pencari nafkah utama keluarga adalah semua orang yang biaya hidupnya tergantung pada pencari nafkah utama tersebut, tidak terbatas hanya pada istri atau suami dan anak-anaknya.

5) Masa kerja, dalam organisasi perlu diketahui masa kerja seseorang karena masa kerja seseorang merupakan satu indikator kecenderungan para pekerja dalam berbagai segi organisasional seperti ; produktivitas kerja dan daftar kehadiran. Semakin lama seseorang bekerja ada kemungkinan untuk mereka mangkir atau tidak masuk kerja disebabkan karena kejenuhan.

b. Kepribadian Kepribadian seseorang juga dapat dipengaruhi motivasi kerja seseorang karena kepribadian sebagai keseluruhan cara yang digunakan oleh seseorang untuk bereaksi dan berinteraksi dengan orang lain.

c. Persepsi Interpretasi seseorang tentang kesan sensorinya mengenai lingkungan sekitarnya akan sangat berpengaruh pada perilaku yang pada gilirannya menentukan faktor-faktor yang dipandangnya sebagai faktor organisasional yang kuat. d. Kemampuan belajar Belajar adalah proses yang berlangsung seumur hidup dan tidak terbatas pada pendidikan formal yang ditempuh seseorang diberbagai tingkat lembaga pendidikan. Salah satu bentuk nyata dari telah belajarnya seseorang adalah perubahan dalam persepsi, perubahan dalam kemauan, dan perubahan dalam tindakan.

e. Nilai-nilai yang dianut Sistem nilai pribadi seseorang biasanya dikaitkan dengan sistem nilai sosial yang berlaku di berbagai jenis masyarakat dimana seseorang menjadi anggota.

f. Sikap Sikap merupakan suatu pernyataan evaluatif seseorang terhadap objek tertentu, orang tertentu atau peristiwa tertentu. Artinya sikap merupakan pencerminan perasaan seseorang terhadap sesuatu.

g. Kepuasan kerja Kepuasan kerja adalah sikap umum seseorang yang positif terhadap kehidupan organisasionalnya.

h. Kemampuan Kemampuan dapat digolongkan atas dua jenis yaitu kemampuan fisik dan kemampuan intelektual. Kemampuan fisik meliputi kemampuan seseorang dalam menyelesaikan tugas-tugas yang bersifat teknis, mekanistik dan repetatif, sedangkan kemampuan intelektual meliputi cara berfikir dalam menghadapi masalah.

Menurut teori kaitan imbalan dengan prestasi (Siagian, 2011), motivasi seorang karyawan sangat dipengaruhi oleh berbagai faktor, baik faktor yang internal maupun eksternal, sebagai berikut:

a. Faktor internal yaitu faktor yang timbul dari dalam diri karyawan antara lain: persepsi, harga diri, harapan pribadi, kebutuhan, keinginan, kepuasan kerja, prestasi kerja yang dihasilkan.

b. Faktor eksternal yaitu faktor yang timbul dari luar diri karyawan antara lain: jenis dan sifat pekerjaan, kelompok kerja dimana seseorang bergabung, organisasi tempat bekerja, situasi lingkungan pada umumnya, 


\section{JURNAL ABDIMAS

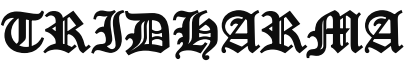

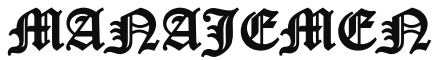

P-ISSN 2615-6849, E-ISSN 2716-070X

Jurnal ABDIMAS Vol. 1,No.2, Mei 2020,Hal(56-66)

@ Prodi Manajemen Fakultas Ekonomi Universitas Pamulang

Email: abdimasjurnal.unpam@ gmail.com Telp: (021) 741-2566 sistem imbalan yang berlaku dan cara penerapannya. Interaksi positif antara kedua kelompok tersebut pada umumnya menghasilkan tingkat motivasi yang tinggi.

Menurut Herzberg (dalam Munandar, 2010), bahwa karyawan termotivasi untuk bekerja disebabkan oleh dua faktor, yaitu:

a. Faktor intrinsik yaitu faktor daya dorong yang timbul dari dalam diri masingkaryawan, berupa:

1) Pekerjaan itu sendiri (the work it self) Berat ringannya tantangan yang dirasakan tenaga kerja dari pekerjaannya.

2) Kemajuan (advancement) Besar kecilnya kemungkinan tenaga kerja berpeluang maju dalam pekerjaannya seperti naik pangkat.

3) Tanggung jawab (responsibility) Besar kecilnya yang dirasakan terhadap tanggung jawab diberikan kepada seorang tenaga kerja.

4) Pengakuan (recognition) Besar kecilnya pengakuan yang diberikan kepada tenaga kerja atas hasil kerja.

5) Pencapaian (achievement) Besar kecilnya kemungkinan tenaga kerja mencapai prestasi kerja tinggi.

b. Faktor ekstrinsik yaitu faktor pendorong yang datang dari luar diri seseorang terutama dari organisasi tempatnya bekerja. Faktor ekstrinsik ini mencakup :

1) Administrasi dan kebijakan perusahaan Tingkat kesesuaian yang dirasakan tenaga kerja terhadap semua kebijakan dan peraturan yang berlaku dalam perusahaan.

2) Penyeliaan Tingkat kewajaran penyelia dirasakan yang oleh tenaga kerja.

3) Gaji kewajaran gaji yang diterima sebagai imbalan terhadap tugas pekerjaan.

4) Hubungan antar pribadi Tingkat kesesuaian yang dirasakan dalam berinteraksi antar tenaga kerja lain.
5) Kondisi kerja Tingkat kesesuaian kondisi kerja dengan proses pelaksanaan tugas pekerjaanpekerjaannya. Apabila faktor intrinsik tersebut ada, dapat memberi tingkat motivasi yang kuat dan kepuasan dalam diri seseorang, namun jika faktor ini tidak ada, maka menimbulkan rasa ketidakpuasan. Sementara faktor ekstrinsik tersebut ada, tidak perlu memberi motivasi, tetapi jika tidak ada dapat menimbulkan tidak puas.

Menurut Rowland \& Rowland (dalam Nursalam, 2002), dalam meningkatkan kepuasan karyawan didasarkan pada faktor-faktor motivasi, yang meliputi:

a. Keinginan untuk peningkatan.

b. Percaya bahwa gaji yang didapat sudah mencukupi

c. Memiliki kemampuan pengetahuan, keterampilan dan nilai-nilai yang diperlukan.

d. Umpan balik.

\section{Cara Meningkatkan Motivasi Kerja}

Ada dua cara pokok seorang pemimpin untuk meningkatkan motivasi kerja (Munandar, 2010), yaitu:

a. Bekerja keras Dengan memaksakan tenaga kerja untuk bekerja keras atau dengan memberikan ancaman, dapat membuat tenaga kerja, kalau tidak dapat menghindarkan diri dari situasi yang mengancam tersebut, akan bekerja keras. Misalnya atasan ingin menegakkan disiplin kerja sehingga menuntuk bawahannya datang tepat waktu dan tampak selama jam-jam kerja terus melaksanakan tugas mereka sampai berakhirnya jam kerja mereka, serta mengancam akan menghukum mereka yang sekian kali tidak datang tepat pada waktunya, atau yang tampak malas pada pekerjaannya. Jika bawahan merasa tidak dapat keluar dari perusahaannya (karena banyak penangguran sehingga sulit sekali mendapatkan pekerjaan baru), maka ia akan berusaha akan selalu datang tepat 


\section{JURNAL ABDIMAS

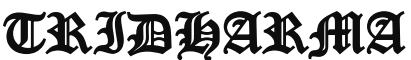

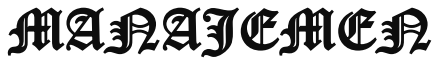

pada waktunya dan akan tampak bekerja selama jam-jam kerja.

b. Memberi tujuan yang bermakna Bersama-sam dengan tenaga kerja yang bersangkutan ditemukan tujuantujuan yang bermakna, sesuai dengan kemampuannya, yang dapat dicapai melalui prestasi kerjanya yang tinggi. Misalnya tenaga kerja mengharapkan mampu mencicil rumah untuk dirinya setelah bekerja lima tahun pada perusahaan. Cicilan setiap bulannya tidak memberatkannya dan akan selesai dalam 10 tahun. Jika kebijakan perusahaan memungkinkan, maka ia akan bekerja dengan motivasi kerja yang tinggi.

\section{MATERI DAN METODE PELAKSANAAN}

\section{Kerangka Pemecahan Masalah}

Mengacu pada permasalahan tersebut,pengabdian kepada masyarakat ini dilakukan ingin membantu secara soisal melalui pendidikan/penyuluhan pada kelurahan pisangan Kec. Ciputat Timur Kota Tangerang Selatan Proponsi Banten. Dengan adanya kegiatan penyuluhan ini diharapkan memberikan kontribusi moral/sosial sehingga akan dapat merubah mindset kerja pada masing-masing individu/staf dan karyawan menjadi lebih baik dan menjadikan kinerja yang positif. Dan mengutip dari Rencana Strategis merupakan suatu proses yang berorientasi kepada hasil yang ingin dicapai selama kurun waktu satu sampai dengan lima tahun dengan memperhitungkan potensi, peluang, dan kendala yang ada atau yang mungkin timbul.

\section{Realisasi Pemecahan Masalah}

Demi kelancaran Kegiatan

Pengabdian Masyarakat (PKM) in,i kami akan berkunjung dan melakukan pembinaan secara berkala ke kelurahan Pisangan Kel. Legoso Kec. Ciputat Kota Tangerang Selatan Banten. kegiatan ini menggunakan metode penyuluhan serta setelah kegiatan selesai akan ada monitoring bersama.

\section{Khalayak Sasaran}

Sasaran dalam pengabdian ini adalah karyawan yang bekerja di kelurahan pisangan ciputat timur.

\section{Tempat dan Waktu}

Kegiatan ini dilakukan di Kelurahan Pisangan Ciputat Timur. Pada tanggal 2528 Januari 2020.

\section{Metode Kegiatan}

Metode kegiatan ini berupa pemaparan materi/presentasi ilmu manajemen. Berikut ini adalah tahapan yang dilakukan :

\section{Tahap Persiapan}

Tahap persiapan yang dilakukan meliputi :

a. Survei awal, pada tahap ini dilakukan survei kelokasi Kelurahan Pisangan yang berada di Ciputat Timur.

b. Pemantapan dan penentuan lokasi dan sasaran. Setelah survei maka ditentukan lokasi pelaksanaan dan sasaran peserta kegiatan.

c. Penyusunan bahan / materi yang meliputi: slide dan makalah untuk kegiatan pelatihan ilmu manajemen.

\section{TahapPelaksanaanPelatihan}

Tahap ini akan memaparkan secara jelas tentang pentingnya ilmu manajemen, dengan menitikberatkan pada penjelasan mengenai bagaimana menjadi sumber daya manusia yang berkualitas dan inovatif, serta pengembangan motivasi kerja karyawan. Selanjutnya dilakukan tahap sharing pengalaman atau pun diskusi tanyajawab. 


\section{JURNAL ABDIMAS

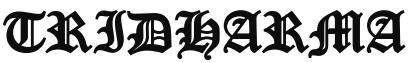

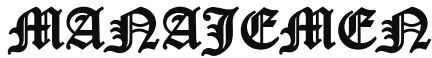

P-ISSN 2615-6849, E-ISSN 2716-070X

Jurnal ABDIMAS Vol. 1,No.2, Mei 2020,Hal(56-66)

@ Prodi Manajemen Fakultas Ekonomi Universitas Pamulang

Email: abdimasjurnal.unpam@ gmail.com Telp: (021) 741-2566

\section{HASIL DAN PEMBAHASAN}

Motivasi kerja dimiliki oleh setiap manusia, tetapi ada sebagian orang yang lebih giat bekerja dari pada yang lain. Kebanyakan orang mau bekerja lebih keras jika tidak menemui hambatan merealisasikan apa yang diharapkan.selama dorongan kerja itu kuat, semakin besar peluang individu untuk lebih konsisten pada tujuan kerja. Namun demikian ada motivasi tertentu yang sebenarnya timbul dalam diri manusia karena terbukanya hati manusia terhadap hidayah Allah. Motivasi itu sendiri dalam Islam sangat terkait dengan masalah niat. Karena niat pun merupakan sebuah pendorong dalam melakukan sebuah kegiatan. Maka penggerak dan pendorong itu tidak jauh dari naluri baik bersifat negatif ataupun positif. Motivasi kerja dalam Islam menurut Muwafik Saleh yaitu : 1) Niat baik dan benar (mengharap ridha Allah SWT). Niat inilah yang menentukan arah pekerjaan, jika niat bekerja hanya ingin mendapatkan gaji maka hanya itulah yang akan didapat. Jika niat bekerja sekaligus untuk menambah simpanan akhirat, manambah harta halal, serta menafkahi keluarga, tentu akan mendapat sebagaimana yang di niatkan. 2) Takwa dalam bekerja. Taat melaksanakan perintahnya dan menjauhi larangannya. Orang yang bertakwa dalam bekerja adalah orang yang mampu bertanggung jawab terhadap segala tugas yang diamanahkan. 3) Iklas dalam bekerja. Iklas adalah syarat kunci diterimanya amal perbuatan manusia disisi Allah SWT, suatu kegiatan atau aktifitas termasuk kerja jika dilakukan dengan iklas maka akan mendatangkan rahmat dari Allah SWT.

\section{KESIMPULAN DAN SARAN}

\section{Kesimpulan}

Kinerja dalam kerangka organisasi terdapat hubungan antara kinerja perorangan (individual Performance) dengan kinerja organisasi (Organization Performance). Suatu organisasi pemerintah maupun swasta besar maupun kecil dalam mencapai tujuan yang telah ditetapkan harus melalui kegiatan-kegiatan yang digerakkan oleh orang atau sekelompok orang yang aktif berperan sebagai pelaku. Kinerja adalah gambaran tentang tingkat pencapaian pelaksanaan suatu kegiatan, program, kebijakan dalam mewujudkan sasaran, tujuan, misi dan visi suatu organisasi. Menurut Mursi dan Wibisono kinerja religius Islam adalah suatu pencapaian yang diproleh seseorang atau organisasi dalam bekerja/berusaha yang mengikuti kaidah-kaidah agama atau prinsip-prinsip ekonomi Islam. Terdapat beberapa dimensi kinerja Islami meliputi : 1) Amanah dalam bekerja yang terdiri atas profesional, jujur, ibadah dan amal perbuatan, 2) Mendalami agama dan profesi terdiri atas memahami tata nilai agama, dan tekun bekerja.

\section{Saran}

1. Bagi Pimpinan Kelurahan Pisangan. guna meningkatkan motivasi dalam kinerja pegawai diharapkan pihak Kelurahan memperhatikan lagi bentuk motivasi kerja pegawai seperti prestasi, karena apabila pegawai merasa termotivasi dalam bekerjanya maka kinerja juga akan lebih baik lagi, dengan cara pimpinan memberikan penghargaan kepada pegawai yang memiliki kemampuan dan memiliki prestasi. Tingginya motivasi kerja yang membuat pegawai nyaman dan sigap dalam mengerjakan tugasnya Pimpinan harus mengadakan pelatihan/sosialisasi tentang tugas dan fungsi sebagai karyawan atau pegawai dalam menunjang pelaksanaan tugas dan fungsi kerjanya.

2. Bagi Aparatur Sebagai bahan masukan untuk sejauh mana mengevaluasi pegawai tentang motivasi kerja serta memperhatikan unsur-unsur apa yang membuat pegawai termotivasi dalam meningkatkan kinerja, sehingga nantinya tidak merugikan Aparatur. 


\section{JURNAL ABDIMAS

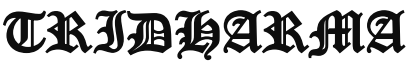

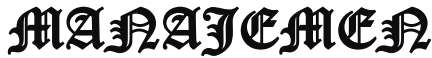

P-ISSN 2615-6849, E-ISSN 2716-070X

Jurnal ABDIMAS Vol. 1,No.2, Mei 2020,Hal(56-66)

@Prodi Manajemen Fakultas Ekonomi Universitas Pamulang

Email: abdimasjurnal.unpam@gmail.com Telp: (021) 741-2566
3. Bagi Pengabdi yang akan datang, tim menyarankan agar dapat menambah materi pelatihan lainnya dalam melihat pengaruh kinerja sehingga hasilnya yang dicapai lebih optimal dan dapat memperluas pengetahuan atau wawasan.

\section{DAFTAR PUSTAKA}

Pasaribu, V. L. D., Agrasadya, A., Shabrina, N., \& Krisnaldy, K. (2020). MENJADI ENTERPRENEUR MUDA YANG MEMILIKI JIWA LEADERSHIP UNTUK MENGHADAPI MASA DEPAN. Abdi Laksana, 1(1).

Pasaribu, V. L. D., Elburdah, R. P., Sudarso, E., \& Fauziah, G. (2020). PENGGUNAAN MANAJEMEN WAKTU TERHADAP PENINGKATAN PRESTASI BELAJAR DI SMP ARAISIYAH. Jurnal ABDIMAS, 1(1).

Pasaribu, V. L. D., Susanti, F., \& Hartuti, E. T. K. (2019). MEMOTIVASI SISWA DAN SISWI SMK LETRIS INDONESIA DI DALAM MENENTUKAN PILIHAN UNTUK MELANJUTKAN

PENDIDIKAN ATAU BEKERJA SETELAH LULUS SEKOLAH. Jurnal Pengabdian Dharma Laksana, 1(2), 161172.

Priyono, Pengantar Manajemen, Cetakan Pertama, Zifatama Publisher, Surabaya, 2007 Purnaya, I Gusti Ketut, Manajemen Sumber Daya Manusia, CV.Andi Offset, 2016

Sutrisno Edy, 2017, Sumber daya manusia, Cetakan ketiga, Kencana, Jakarta https://text-

id.123dok.com/document/ozlgkl1 oy-gambaran-umum-masyarakatkelurahan-pisangankecamatan- ciputat-timur.htm tanggal 24 Oktober 2019

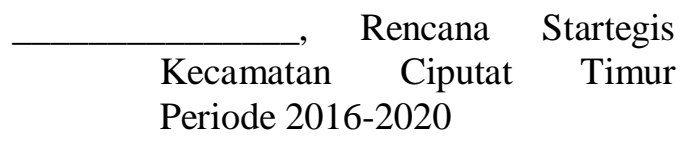

(Warning! Copyright 2019 by Universitas Psikologi) Sumber Artikel: https://www.universitasp sikologi.com/2018/10/pengertian -motivasi-kerja-danmeningkatkan-motivasikerja.html

\section{DOKUMENTASI FOTO KEGIATAN}
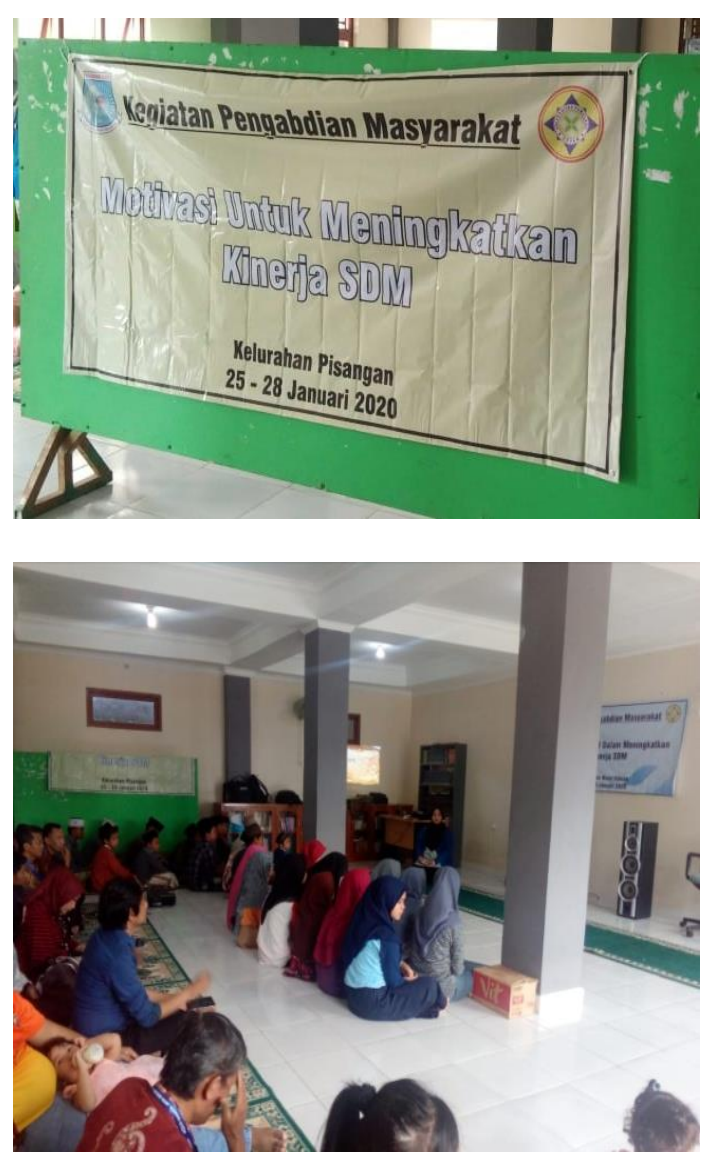

JURNAL ABDIMAS
P-ISSN 2615-6849, E-ISSN 2716-070X

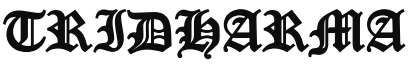
Jurnal ABDIMAS Vol. 1,No.2, Mei 2020,Hal(56-66)

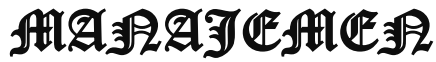
@Prodi Manajemen Fakultas Ekonomi Universitas Pamulang
Email: abdimasjurnal.unpam@ gmail.com Telp: (021) 741-2566
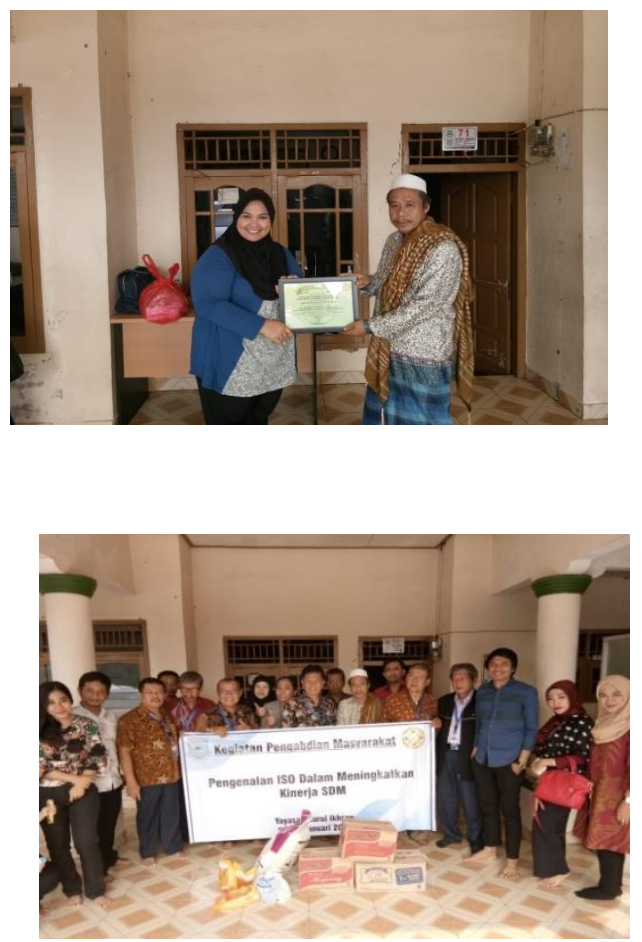